\title{
$\square$
}

\section{Urban Decentralization and Income Inequality: Is Sprawl Associated with Rising Income Segregation Across Neighborhoods?}

\author{
Christopher H. Wheeler
}

\begin{abstract}
Existing research shows an inverse relationship between urban density and the degree of income inequality within metropolitan areas; this information suggests that as urban areas spread out, they become increasingly segregated by income. This paper examines this hypothesis using data covering more than 165,000 block groups within 359 U.S. metropolitan areas for the years 1980, 1990, and 2000. The findings indicate that income inequality-defined by the variance of the log household income distribution-does indeed rise significantly as urban density declines. This increase, however, is associated with rising inequality within block groups as cities spread farther from their central core. The extent of income variation between different block groups, by contrast, shows virtually no association with population density. Accordingly, little evidence supports the notion that urban sprawl is systematically associated with greater residential segregation of households by income. (JEL D31, R11, R23)
\end{abstract}

Federal Reserve Bank of St. Louis Regional Economic Development, 2008 4(1), pp. 41-57.

F or much of the past century, the population within U.S. metropolitan areas has shown a persistent tendency to move outward as residents leave central cities for suburban locales. This movement has been striking within the past 50 years. In 1950, 41.5 percent of metropolitan populations resided in suburban areas (i.e., those outside central cities); a half century later, more than 62 percent did. As a consequence, the density of population within the nation's urban areas has changed dramatically. Between 1950 and 2000, the average central-city population density decreased from 7,517 residents per square mile to 2,716 . At the same time, suburban densities increased from 175 residents per square mile to $208 .^{1}$

1 All of these figures are derived from the U.S. Census of Population and Housing, as reported by Hobbs and Stoops (2002).
Undoubtedly, urban decentralization largely reflects the decisions of individuals and employers to expand their activities over more space. Improved transportation technology and infrastructure, for example, have eased longer commuting distances. These changes have encouraged workers and firms to locate on the outer fringes of their metropolitan areas where land tends to be more plentiful and less costly.

Despite the "voluntary" nature of this process, urban decentralization has generated several concerns about the welfare of metropolitan area populations. One such concern is a rising disparity between neighborhoods, especially the decline of incomes in central cities relative to those of their suburban counterparts. As metropolitan areas expand, the majority of both employment opportunities and relatively high-income households may shift from the central core to the periphery,

Christopher H. Wheeler was a research officer at the Federal Reserve Bank of St. Louis at the time this article was written.

(C) 2008, The Federal Reserve Bank of St. Louis. The views expressed in this article are those of the author(s) and do not necessarily reflect the views of the Federal Reserve System, the Board of Governors, or the regional Federal Reserve Banks. Articles may be reprinted, reproduced, published, distributed, displayed, and transmitted in their entirety if copyright notice, author name(s), and full citation are included. Abstracts, synopses, and other derivative works may be made only with prior written permission of the Federal Reserve Bank of St. Louis. 
thereby creating a widening income gap between these two areas. Over time, these differences may become more pronounced as the poor become increasingly isolated from productive interactions with wealthier neighbors. ${ }^{2}$

Existing evidence seems to support this idea. Margo (1992), for example, argues that the movement of metropolitan populations in the United States toward suburban locales over the latter half of the twentieth century can be linked, to a significant degree, to the rise in personal incomes. As individual incomes increased, so did the demand for land. One rather straightforward implication of this hypothesis is that decentralization should be accompanied by a rise in the extent of income segregation. Individuals migrating to the suburbs (i.e., those with a particularly high demand for space) should also be those with relatively high incomes. As a result, urban decentralization would be expected to lead to the accumulation of highincome households on the outskirts of cities, while poorer residents remain within the central cores.

A number of studies do suggest that poverty became more concentrated within the country's urban areas over this same period. Mayer (1996) reports that in 1964, families in the bottom quintile of the income distribution were 1.2 times as likely to reside in a central city as wealthier families. By 1994, they were 1.4 times as likely to reside in central cities. In studies of the largest U.S. cities and metropolitan areas, Kasarda (1993) and Abramson, Tobin, and VanderGoot (1995) find that individuals living in poverty became increasingly concentrated within poor neighborhoods (defined by Census tracts) between 1970 and 1990. Although these two particular studies do not consider the issue of urban decentralization per se, the figures documented therein certainly characterize a period during which metropolitan populations were shifting from central areas toward suburban ones.

Research on the spatial mismatch hypothesis offers a similar conclusion. This idea, advanced by Kain (1968), holds that inner-city residents tend to experience adverse economic outcomes as pop-

\footnotetext{
2 The movement of high-income individuals away from the poor, for example, may leave the poor with relatively few jobs (e.g., Kain, 1968) or reduce the extent to which the rich confer positive spillovers on the poor (e.g., Wilson, 1987, and Benabou, 1996).
}

ulation and employment opportunities leave those inner cities because it becomes increasingly difficult for them to find and sustain employment. Therefore, the gap between the incomes earned by residents of suburban neighborhoods and those earned by residents of the central city should be expected to rise as populations spread out. Many studies on this topic have found that inner-city minorities do seem to experience worse labor market outcomes, usually measured by employment status and earnings, as economic activity leaves urban centers, although the literature is far from unanimous on this point. ${ }^{3}$

On the specific topic of income inequality, Wheeler (2004) finds that urban density exhibits a strong negative correlation with the degree of spread more in the distribution of labor earnings. Thus, as a metropolitan area's population spreads out, its wage distribution tends to widen. Although the results apply to white male workers with a strong attachment to the labor force (and so do not offer direct evidence on spatial mismatch, which tends to focus on differences by race), they certainly are consistent with the concept that urban decentralization leads to greater segregation of high-income and low-income workers across neighborhoods.

Despite the findings of existing work, surprisingly little research has directly studied the evolution of interneighborhood income differentials as populations become increasingly dispersed, particularly among neighborhoods defined at levels finer than central cities and suburbs. A notable exception is Yang and Jargowsky (2006), who look at the relationship between sprawl and a neighborhood segregation index based on urban tracts in the United States between 1990 and 2000. This paper performs a related, although different, exercise. In particular, I examine the relationship between urban density and the degree of income inequality both within and between neighborhoods defined by Census block groups. More specifically, I use data on household income to compute the variance of the income distribution for each of 359 U.S. metropolitan areas for the years 1980, 1990, and 2000. I then exploit data covering more than 165,000 block

\footnotetext{
3 See, for example, Ihlanfeldt and Sjoquist (1989), Holzer (1991), and Weinberg $(2000,2004)$ for a discussion of these issues.
} 
groups to decompose these variances into components associated with the dispersion of incomes within block groups and components associated with the dispersion across them.

The results suggest that even though a strong negative association exists in the variance of a metropolitan area's household income distribution and its overall population density, the association operates through a within-neighborhood channel rather than a between-neighborhood channel. That is, as the population of a metropolitan area spreads out, household income inequality increases largely because the extent of income variation among households within the same block group rises, not because neighborhoods become more segregated by income.

On closer inspection, the data do reveal some evidence that decentralization tends to be accompanied by rising between-neighborhood income gaps, but this occurs only at the top of the blockgroup income distribution. Specifically, the income differential between the block group at the 90th percentile of the household income distribution and the block group at the median does increase significantly as metropolitan areas decentralize. However, the gap between the median and the block group at the 10th percentile tends to decrease, which leaves measures of the overall spread in the between-neighborhood income distribution relatively unchanged. Moreover, there appears to be little association between density and either the average income of the block group at the 90th percentile or that of the block group at the 10th percentile. Similar results hold when the analysis is repeated using Census tracts instead of block groups.

Notably, these results should not be interpreted as suggesting that certain neighborhoods do not experience particularly adverse economic outcomes as populations decentralize. Some inner-city areas indeed may become increasingly poor as activity moves outward. However, the extent to which this process occurs evidently has little effect on the overall level of between-neighborhood income inequality in a metropolitan area.

The remainder of the paper proceeds as follows. The next section provides a brief description of the data and some of the computational issues. The results section is followed by concluding remarks.

\section{DATA AND MEASUREMENT}

The primary data source used for the analysis is the decennial U.S. Census of Population and Housing for the years 1980, 1990, and 2000 as compiled by GeoLytics. ${ }^{4}$ The GeoLytics data files report a variety of demographic and economic characteristics (e.g., income, industry of employment, age, race, gender, education, place of birth, employmentunemployment status) for individuals at a variety of geographic levels, including counties, tracts, and block groups. Unfortunately, individual-level observations are not reported in the data; only summary measures taken across the individuals located within each geographic unit are reflected. This feature thereby limits the types of statistics that can be calculated. The primary advantage of these data is the consistency of the geographic units-the data have been constructed based on consistent geographic definitions over all three Census years.

This study focuses on average household income and a variety of other economic and demographic data among residents in block groups, which are used as the basis for a "neighborhood." Although neighborhoods could also be (and frequently are) defined by Census tracts, the focus is on block groups in this paper because they represent the finest grouping available in the data. Across the 359 metro areas in the sample, there are more than 165,000 block groups that each contained, on average, 526.5 households and had a median land area of approximately 0.33 square miles in the year $2000 .^{5}$ Tracts tend to be larger (1,648.8 households, on average, and a median land area of 1.31 square miles in 2000), and therefore, they may be less appropriate when considering neighborhoods, which are meant to encompass areas over which individuals can reasonably be expected to interact with one another. As demonstrated below, the principal findings are mostly invariant to the choice of block groups or tracts.

\footnotetext{
4 The data can be obtained from GeoLytics, Inc. at http://www.geolytics.com.

5 Metropolitan area definitions follow the Census Bureau's definitions as of November 2004. They were accessed at www.census.gov/population/www/estimates/metrodef.html.
} 


\section{Table 1}

\section{Summary Statistics: Block Group Income Inequality}

\begin{tabular}{|c|c|c|c|c|c|}
\hline Year & Variable & Mean & Standard deviation & Minimum & Maximum \\
\hline \multirow[t]{3}{*}{1980} & Variance & 0.55 & 0.06 & 0.43 & 0.75 \\
\hline & Within component & 0.47 & 0.05 & 0.37 & 0.64 \\
\hline & Between component & 0.07 & 0.04 & 0.003 & 0.24 \\
\hline \multirow[t]{3}{*}{1990} & Variance & 0.64 & 0.07 & 0.48 & 0.94 \\
\hline & Within component & 0.50 & 0.05 & 0.39 & 0.65 \\
\hline & Between component & 0.14 & 0.05 & 0.04 & 0.31 \\
\hline \multirow[t]{3}{*}{2000} & Variance & 0.65 & 0.08 & 0.48 & 1.05 \\
\hline & Within component & 0.52 & 0.05 & 0.41 & 0.70 \\
\hline & Between component & 0.13 & 0.05 & 0.02 & 0.38 \\
\hline
\end{tabular}

NOTE: Statistics taken across 359 metropolitan areas.

I estimate the variance of a metropolitan area's income distribution as follows. For each year, the number of households with incomes falling into each of $N$ closed intervals is reported in the GeoLytics files. ${ }^{6}$ I use these figures to compute the fraction of households with incomes less than $N$ distinct levels, which allows $N$ quantiles of the household income distribution to be estimated for each metro area. For example, if 14 percent of all households have income less than $\$ 25,000$, I estimate the 0.14 quantile by 25,000 . Label these quantiles $X_{\alpha}$. I then match these $N$ quantiles to their corresponding values from a normal $(0,1)$ distribution. Label these quantiles $U_{\alpha}$. Assuming a lognormal household income distribution, $X_{\alpha}$ and $U_{\alpha}$ are related as follows:

$$
X_{\alpha}=\exp \left(\zeta+U_{\alpha} \sigma\right),
$$

where $\zeta$ and $\sigma$ are the mean and standard deviation (SD) parameters characterizing the lognormal distribution (see Johnson and Kotz, 1970, p. 117). These parameters are readily obtained by transforming equation (1) logarithmically and estimating by ordinary least squares (OLS). The fit of these regressions tended to be quite high in all cases. Across the 359 metro areas, the mean adjusted $R^{2}$ was approximately 0.98 for each year, and the minimum across

6 For 1980, there are 15 income categories; for 1990, there are 24; for 2000, there are 15. See the Appendix for details. all metro area-year observations was 0.95 . With the $\mathrm{SD}, \sigma$, the variance follows simply as $\sigma^{2}$.

Summary statistics describing metropolitan area-level income variances appear in Table 1. Most notably, they demonstrate that, on average, the degree of dispersion exhibited by metropolitan area-level (log) income distributions increased between 1980 and 2000, with the majority of this increase between 1980 and 1990. Over these two decades, the mean income variance rose by a total of $10 \log$ points (approximately 18 percent). Of this 10 log point increase, the majority - 9 log pointswas experienced during the 1980s. Qualitatively, of course, this finding is consistent with what has now been widely established in the inequality literature (e.g., Katz and Murphy, 1992, Juhn, Murphy, and Pierce, 1993).

\section{EMPIRICAL FINDINGS}

\section{Urban Decentralization and Income Inequality}

Consider first the relationship between metropolitan area-level population density and the extent of income inequality. To do so, let the variance of the (log) income distribution for metropolitan area $m$ in year $t$ have the following characterization:

$$
\sigma_{m t}^{2}=\mu_{m}+\mu_{t}+\beta X_{m t}+\gamma D_{m t}+\varepsilon_{m t},
$$


where $\mu_{m}$ is a metro area-specific fixed effect, $\mu_{t}$ is a year-specific term, $X_{m t}$ is a vector of covariates described in greater detail below, $D_{m t}$ is the logarithm of population density, and $\varepsilon_{m t}$ is a residual. To eliminate the metro area fixed effects, I take 10year differences of equation (2), yielding

$$
\Delta \sigma_{m t}^{2}=\Delta \mu_{t}+\beta \Delta X_{m t}+\gamma \Delta D_{m t}+\Delta \varepsilon_{m t},
$$

which serves as the primary estimating equation in the analysis. Given the nature of the differenced error term, there is nonzero correlation between the residuals for the same metro area. The standard errors are adjusted to account for this correlation.

Density is calculated for each metropolitan area as the weighted average of county-level population densities, where the weights are given by each county's share of total metropolitan area population. This measure is used instead of average metropolitan area density (calculated as the ratio of total metropolitan area population to total land area) to mitigate the influence of extremely large but relatively unpopulated counties, which appear in many metropolitan areas of the West. Countyweighted population density gives these counties less weight in the computations and, therefore, may provide a better sense of how densely clustered a city's population is. ${ }^{7}$ Table 2 lists the 10 most and least densely populated metropolitan areas in each year.

Among the covariates included in the vector $X_{m t}$ are some basic characteristics commonly associated with the degree of income inequality in an economy. These characteristics include the percentages of the resident population that are black, female, foreign-born, younger than age 25, and older than age 65 ; the fraction of the population 25 years of age or older that has completed at least a bachelor's degree; shares of employment in 9 broad industries ${ }^{8}$; the fraction of the labor force

\footnotetext{
7 I also repeated all of the estimations using weighted averages of block group-level population densities for each metro area. The results were qualitatively similar to those reported here.

8 The sectors are manufacturing; agriculture, forestry, fisheries, and mining; construction; wholesale trade; retail trade; finance, insurance, real estate; public administration; education services; health services. I do not use a more detailed industrial classification scheme, in part, to avoid difficulties associated with the change from the Standard Industrial Classification system in 1980 and 1990 to the North American Industry Classification System in 2000.
}

that is represented by a union; and the unemployment rate. I also include three region dummies to account for any basic geographic differences in the inequality trends across different parts of the country. ${ }^{9}$

Results of these characteristics appear in Table 3. I consider three different specifications of the covariates in the estimation of equation (3) to gauge the robustness of the density-inequality relationship. The first limits the regressors to log density, the three region dummies, and a time effect for the 1980-90 decade. The second then adds the population demographics of each metro area (age, race, gender, education, foreign-born status). The third includes the remainder of the covariates that provide a basic description of the metro area's labor market (industry employment shares, unionization, unemployment). ${ }^{10}$

Several fairly standard findings are evident. Larger proportions of women and individuals younger than age 24 in the local population are strongly, positively associated with inequality, which likely reflects the relatively low average income among these individuals. Some evidence (although not always statistically significant) indicates that inequality increases with the percentages of foreign-born residents and individuals older than age 65 in the local population. Furthermore, inequality in a metro area tends to rise significantly as the unemployment rate increases, suggesting that households at the bottom end of the income distribution are more sensitive economically to the business cycle than wealthier households. Inequality is also significantly, negatively associated with the extent of union coverage in the local labor force, which is a relatively common finding. Although union workers typically receive an earnings premium over nonunion labor, union contracts tend to equalize earnings across workers (e.g., Fortin

\footnotetext{
9 Because metropolitan area boundaries frequently cross state borders and region definitions are based on states, parts of some metro areas are in different regions. I assign these multiregion metropolitan areas to the regions in which the majority of their populations lie.

10 The unionization rate for each metropolitan area is based on statelevel union coverage rates reported by Hirsch, Macpherson, and Vroman (2001) (available at www.unionstats.com). Metropolitan area-level union rates are calculated as weighted averages of their constituent state-level rates, where the weights are given by the fraction of each metro area's labor force located in each state.
} 
Table 2

\section{Most and Least Densely Populated Metro Areas}

\begin{tabular}{|c|c|c|c|c|}
\hline Year & Top 10 & Density & Bottom 10 & Density \\
\hline \multirow[t]{10}{*}{1980} & New York-Northern New Jersey-Long Island, NY-NJ-PA & $14,740.0$ & Flagstaff, AZ & 4.03 \\
\hline & Philadelphia-Camden-Wilmington, PA-NJ-DE-MD & $4,927.0$ & Prescott, AZ & 8.4 \\
\hline & Washington-Arlington-Alexandria, DC-VA-MD-WV & $4,374.1$ & St. George, UT & 10.7 \\
\hline & Baltimore-Towson, MD & $4,017.3$ & Casper, WY & 13.5 \\
\hline & San Francisco-Oakland-Fremont, CA & $3,996.1$ & Wenatchee, WA & 14.3 \\
\hline & Chicago-Naperville-Joliet, IL-IN-WI & $3,959.4$ & Farmington, NM & 14.8 \\
\hline & Boston-Cambridge-Quincy, MA-NH & $2,930.6$ & Yuma, AZ & 16.4 \\
\hline & Milwaukee-Waukesha-West Allis, WI & $2,885.7$ & Bend, OR & 20.6 \\
\hline & Detroit-Warren-Livonia, MI & $2,556.5$ & Rapid City, SD & 20.9 \\
\hline & Cleveland-Elyria-Mentor, $\mathrm{OH}$ & $2,435.9$ & El Centro, CA & 22.1 \\
\hline \multirow[t]{10}{*}{1990} & New York-Northern New Jersey-Long Island, NY-NJ-PA & $15,161.5$ & Flagstaff, AZ & 5.2 \\
\hline & Philadelphia-Camden-Wilmington, PA-NJ-DE-MD & $4,385.6$ & Casper, WY & 11.5 \\
\hline & San Francisco-Oakland-Fremont, CA & $4,171.9$ & Prescott, AZ & 13.3 \\
\hline & Washington-Arlington-Alexandria, DC-VA-MD-WV & $3,886.3$ & Farmington, NM & 16.6 \\
\hline & Chicago-Naperville-Joliet, IL-IN-WI & $3,783.4$ & Wenatchee, WA & 16.7 \\
\hline & Baltimore-Towson, MD & $3,440.1$ & Yuma, AZ & 19.4 \\
\hline & Boston-Cambridge-Quincy, MA-NH & $2,942.5$ & St. George, UT & 20.0 \\
\hline & Milwaukee-Waukesha-West Allis, WI & $2,806.9$ & Rapid City, SD & 24.4 \\
\hline & Los Angeles-Long Beach-Santa Ana, CA & $2,369.0$ & Bend, OR & 24.8 \\
\hline & Detroit-Warren-Livonia, MI & $2,292.3$ & El Centro, CA & 26.2 \\
\hline \multirow[t]{10}{*}{2000} & New York-Northern New Jersey-Long Island, NY-NJ-PA & $16,125.0$ & Flagstaff, AZ & 6.2 \\
\hline & San Francisco-Oakland-Fremont, CA & $4,419.8$ & Casper, WY & 12.5 \\
\hline & Philadelphia-Camden-Wilmington, PA-NJ-DE-MD & 4,027.1 & Prescott, AZ & 20.6 \\
\hline & Chicago-Naperville-Joliet, IL-IN-WI & $3,880.0$ & Farmington, NM & 20.6 \\
\hline & Washington-Arlington-Alexandria, DC-VA-MD-WV & $3,573.1$ & Wenatchee, WA & 21.2 \\
\hline & Boston-Cambridge-Quincy, MA-NH & $3,036.4$ & Rapid City, SD & 26.5 \\
\hline & Baltimore-Towson, MD & $2,813.0$ & Yuma, AZ & 29.0 \\
\hline & Milwaukee-Waukesha-West Allis, WI & $2,634.7$ & Great Falls, MT & 29.8 \\
\hline & Los Angeles-Long Beach-Santa Ana, CA & $2,634.6$ & Cheyenne, WY & 30.4 \\
\hline & Detroit-Warren-Livonia, MI & $2,231.9$ & Duluth, MN-WI & 32.9 \\
\hline
\end{tabular}

NOTE: Population densities are calculated as (population-share) weighted averages of county-level densities (in residents per square mile). 


\section{Table 3}

\section{Overall Inequality Results}

\begin{tabular}{|c|c|c|c|}
\hline Variable & $I$ (SE) & II (SE) & III (SE) \\
\hline Log density & $-0.07 *(0.009)$ & $-0.086^{*}(0.01)$ & $-0.07^{*}(0.01)$ \\
\hline Percent bachelor's degree & - & $0.54 *(0.08)$ & $0.52 *(0.09)$ \\
\hline Percent female & - & $0.73 *(0.28)$ & $0.44 *(0.25)$ \\
\hline Percent black & - & $0.05(0.11)$ & $0.03(0.10)$ \\
\hline Percent $<24$ years & - & $0.35 *(0.14)$ & $0.23 *(0.13)$ \\
\hline Percent $>65$ years & - & $0.31 *(0.16)$ & $0.23(0.15)$ \\
\hline Percent foreign-born & - & $0.28 *(0.13)$ & $0.20(0.13)$ \\
\hline Percent manufacturing & - & - & $-0.35 *(0.07)$ \\
\hline Percent agriculture, forestry, fishing, and mining & - & - & $-0.04(0.11)$ \\
\hline Percent construction & - & - & $-0.28^{*}(0.12)$ \\
\hline Percent wholesale trade & - & - & $-0.10(0.15)$ \\
\hline Percent retail trade & - & - & $0.11(0.11)$ \\
\hline Percent finance, insurance, and real estate & - & - & $-0.46^{*}(0.15)$ \\
\hline Percent public administration & - & - & $-0.34 *(0.14)$ \\
\hline Percent education services & - & - & $-0.28 *(0.13)$ \\
\hline Percent health services & - & - & $0.11(0.13)$ \\
\hline Unemployment rate & - & - & $0.46^{*}(0.08)$ \\
\hline Percent union representation & - & - & $-0.12 *(0.05)$ \\
\hline$R^{2}$ & 0.64 & 0.69 & 0.74 \\
\hline
\end{tabular}

NOTE: Data represent 718 observations. The dependent variable is the change in the variance of the log income distribution for a metropolitan area. Each regressor is expressed in terms of contemporaneous 10-year changes. All specifications also include three region dummies and a time effect for the 1980-90 decade. Standard errors (reported in parentheses) are adjusted for both heteroskedasticity and withinmetro area correlation of the regression error terms. *Significant at $\geq 10$ percent.

and Lemieux, 1997). Shares of local employment in manufacturing and construction-two sectors frequently associated with relatively high earnings for relatively low-skilled labor-correlate negatively with income inequality.

The primary regressor of interest, the logarithm of population density, is uniformly negative and statistically significant across all three specifications. Based on the point estimates, a 1 SD decrease in the change in population density corresponds to a 1 log point increase in the change in log income variance. This figure is far from negligible, representing approximately 20 percent of the mean change in log income variance over the two decades considered in this study. Again, this basic finding has already been established, at least in a qualitative sense, in some of the works previously described.
The following text takes a closer look at this result to determine the extent to which it reflects an increase in the degree of income segregation across neighborhoods.

\section{Decomposing Income Inequality}

Consider the following standard decomposition of a metropolitan area's income inequality. The variance of household income in a metropolitan area, $\sigma^{2}$, can be estimated as

$$
\sigma^{2}=\frac{1}{H} \sum_{n=1}^{N} \sum_{h=1}^{H_{n}}\left(y_{h, n}-\bar{y}\right)^{2},
$$

where $y_{h, n}$ is the income of household $h$ of neighborhood $n, \bar{y}$ is the mean household income for the entire metropolitan area, $H_{n}$ is the total number of 
households in neighborhood $n, N$ is the total number of neighborhoods, and $H$ is the total number of households, $\Sigma_{n} H_{n}$. ${ }^{11}$ This expression can be rewritten as the sum of two terms:

$$
\sigma^{2}=\frac{1}{H} \sum_{n=1}^{N} \sum_{h=1}^{H_{n}}\left(y_{h, n}-\bar{y}_{n}\right)^{2}+\frac{1}{H} \sum_{n=1}^{N} \sum_{h=1}^{H_{n}}\left(\bar{y}_{n}-\bar{y}\right)^{2},
$$

where $\bar{y}_{n}$ represents the mean household income in neighborhood $n$. The first of the terms on the right-hand side of equation (5) is the "within" neighborhood component, which measures the degree of income dispersion among households within the same neighborhood. The second term, the "between" component, captures the amount of income variation across different neighborhoods.

The within component cannot be computed directly because data from individual households are unavailable. However, the between component can be computed. Using the estimates of the variance, $\sigma^{2}$, derived above, the within-neighborhood component is constructed as the difference between these two pieces.

Table 1 lists some summary statistics describing the within-block and between-block group components. Two features are immediately apparent. First, in each of the three years considered (1980, 1990, 2000), the extent of income variation within neighborhoods is considerably larger than the extent of variation between them. In the year 2000, for instance, the within-neighborhood component accounted for 80 percent of total metropolitan area income variation, on average. This finding is roughly similar to Epple and Sieg's (1999) report for municipalities in Boston and is consistent with the results of Ioannides (2004) and Hardman and Ioannides (2004), who document a substantial degree of income heterogeneity within small residential clusters in the United States. Second, the 10 years between 1980 and 1990 saw a sharp rise in the proportion of total income variation attributable to between-neighborhood differences. Over this decade, the average fraction of total income variation associated with differences across neigh-

\footnotetext{
${ }^{11}$ The average numbers of households per metropolitan area are relatively large: $180,164.6$ for 1980, 208,780.9 for 1990, and 240,407.2 for 2000. Across all three years, the minimum number of households is 8,681 . Hence, the difference between using a factor of $1 / H$ in equation (4) instead of $1 /(H-1)$ is extremely small.
}

borhoods rose from 12.7 percent to 21.9 percent. Hence, although income variation remained predominantly a within-neighborhood phenomenon in 2000, the between-neighborhood component became increasingly important between 1980 and 2000 .

\section{Decentralization and Inequality: Within versus Between Neighborhoods}

An estimated series of regressions following the above procedure was used to determine whether urban decentralization is associated with growing inequality through a within- or a betweenneighborhood channel (or possibly both). I estimate three specifications of equation (3) in which the dependent variables are the changes in within- and between-neighborhood income variation rather than the change in the total variance of log income.

The estimates are shown in Table 4. Interestingly, they demonstrate some striking differences in the estimated associations across the two sets of results. In looking just at the longest specification, III, the change in a metro area's degree of income variation within its block groups is positively and significantly tied to changes in the fraction of the population with a bachelor's degree, the fraction that is black, and the fraction that is foreign-born. On the other hand, increases in the percentages of total employment in manufacturing and finance, insurance, and real estate correlate negatively with income inequality within neighborhoods.

Between-neighborhood inequality shows a similar positive and significant association with the fraction of college graduates in the local population and with a number of quantities that did not relate significantly to within-block group inequality: the percentages of the population accounted for by women, individuals younger than age 24 , and the unemployment rate. Increases in these three variables tend to be associated with increases in the extent of income variation between different block groups. In addition, between-neighborhood inequality is significantly, negatively tied to the fraction of the local population that is black, the shares of total employment accounted for by construction and education services, and the extent of union representation in the local labor force. 


\section{Table 4}

\section{Within- and Between-Neighborhood Inequality Results}

\begin{tabular}{|c|c|c|c|c|c|c|}
\hline \multirow[b]{2}{*}{ Variable } & \multicolumn{3}{|c|}{ Within-neighborhood } & \multicolumn{3}{|c|}{ Between-neighborhood } \\
\hline & $I$ & II & III & I & II & III \\
\hline Log density & $\begin{array}{c}-0.069 * \\
(0.009)\end{array}$ & $\begin{array}{c}-0.075^{*} \\
(0.01)\end{array}$ & $\begin{array}{c}-0.064^{*} \\
(0.01)\end{array}$ & $\begin{array}{c}-0.001 \\
(0.008)\end{array}$ & $\begin{array}{l}-0.01 \\
(0.009)\end{array}$ & $\begin{array}{c}-0.006 \\
(0.008)\end{array}$ \\
\hline Percent bachelor's degree & - & $\begin{array}{c}0.38^{*} \\
(0.08)\end{array}$ & $\begin{array}{c}0.35^{*} \\
(0.09)\end{array}$ & - & $\begin{array}{c}0.16^{*} \\
(0.07)\end{array}$ & $\begin{array}{c}0.17^{*} \\
(0.08)\end{array}$ \\
\hline Percent female & - & $\begin{array}{c}-0.006 \\
(0.21)\end{array}$ & $\begin{array}{c}-0.004 \\
(0.23)\end{array}$ & - & $\begin{array}{c}0.73^{*} \\
(0.20)\end{array}$ & $\begin{array}{c}0.44^{*} \\
(0.17)\end{array}$ \\
\hline Percent black & - & $\begin{array}{c}0.24^{*} \\
(0.11)\end{array}$ & $\begin{array}{c}0.24^{*} \\
(0.11)\end{array}$ & - & $\begin{array}{c}-0.19 * \\
(0.10)\end{array}$ & $\begin{array}{c}-0.21^{*} \\
(0.10)\end{array}$ \\
\hline Percent $<24$ years & - & $\begin{array}{c}0.10 \\
(0.12)\end{array}$ & $\begin{array}{c}0.06 \\
(0.12)\end{array}$ & - & $\begin{array}{c}0.25^{*} \\
(0.11)\end{array}$ & $\begin{array}{c}0.17^{*} \\
(0.11)\end{array}$ \\
\hline Percent $>65$ years & - & $\begin{array}{c}0.37^{*} \\
(0.15)\end{array}$ & $\begin{array}{c}0.22 \\
(0.14)\end{array}$ & - & $\begin{array}{c}-0.06 \\
(0.16)\end{array}$ & $\begin{array}{c}0.01 \\
(0.15)\end{array}$ \\
\hline Percent foreign-born & - & $\begin{array}{c}0.21^{*} \\
(0.10)\end{array}$ & $\begin{array}{c}0.18^{*} \\
(0.09)\end{array}$ & - & $\begin{array}{c}0.07 \\
(0.06)\end{array}$ & $\begin{array}{c}0.024 \\
(0.06)\end{array}$ \\
\hline Percent manufacturing & - & - & $\begin{array}{c}-0.27^{*} \\
(0.07)\end{array}$ & - & - & $\begin{array}{c}-0.08 \\
(0.05)\end{array}$ \\
\hline Percent agriculture, forestry, fishing, and mining & - & - & $\begin{array}{c}-0.13 \\
(0.12)\end{array}$ & - & - & $\begin{array}{c}0.09 \\
(0.11)\end{array}$ \\
\hline Percent construction & - & - & $\begin{array}{c}0.035 \\
(0.12)\end{array}$ & - & - & $\begin{array}{c}-0.32^{*} \\
(0.10)\end{array}$ \\
\hline Percent wholesale trade & - & - & $\begin{array}{c}0.10 \\
(0.17)\end{array}$ & - & - & $\begin{array}{c}-0.19 \\
(0.15)\end{array}$ \\
\hline Percent retail trade & - & - & $\begin{array}{c}0.03 \\
(0.10)\end{array}$ & - & - & $\begin{array}{c}0.08 \\
(0.09)\end{array}$ \\
\hline Percent fire, insurance, and real estate & - & - & $\begin{array}{c}-0.26^{*} \\
(0.14)\end{array}$ & - & - & $\begin{array}{c}-0.20 \\
(0.13)\end{array}$ \\
\hline Percent public administration & - & - & $\begin{array}{c}-0.18 \\
(0.13)\end{array}$ & - & - & $\begin{array}{c}-0.16 \\
(0.10)\end{array}$ \\
\hline Percent education services & - & - & $\begin{array}{c}0.12 \\
(0.15)\end{array}$ & - & - & $\begin{array}{c}-0.39 * \\
(0.14)\end{array}$ \\
\hline Percent health services & - & - & $\begin{array}{c}0.02 \\
(0.13)\end{array}$ & - & - & $\begin{array}{c}0.09 \\
(0.11)\end{array}$ \\
\hline Unemployment rate & - & - & $\begin{array}{c}0.02 \\
(0.09)\end{array}$ & - & - & $\begin{array}{c}0.44^{*} \\
(0.09)\end{array}$ \\
\hline Percent union representation & - & - & $\begin{array}{c}0.01 \\
(0.05)\end{array}$ & - & - & $\begin{array}{c}-0.13^{*} \\
(0.05)\end{array}$ \\
\hline$R^{2}$ & 0.17 & 0.23 & 0.28 & 0.66 & 0.68 & 0.72 \\
\hline
\end{tabular}

NOTE: Data represent 718 observations. Dependent variables are the changes in within- and between-neighborhood income variation for a metropolitan area. Each regressor is expressed in terms of contemporaneous 10-year changes. All specifications also include three region dummies and a time effect for the 1980-90 decade. Standard errors (reported in parentheses) are adjusted for both heteroskedasticity and within-metro area correlation of the regression error terms. ${ }^{*}$ Significant at $\geq 10$ percent. 
Why are there such differences in the associations of these variables with the two measures of inequality? One possible explanation relates to how residential patterns change with each quantity. Increases in the fraction of black residents in a metro area's total population, for instance, may be associated with increasing racial heterogeneity within block groups (hence, higher withinneighborhood income variation), and as a consequence, declining heterogeneity between them (thus, lower between-neighborhood variation). Similarly, fluctuations in unemployment and union membership may influence workers in particular neighborhoods much more than a city's general population. This would lead to fluctuations in the degree of inequality between neighborhoods rather than within them.

For the variable of primary interest-population density - the results demonstrate a clear, negative association with the extent of income variation within neighborhoods. As the change in population density decreases by 1 SD in the cross section, the change in (log) income variance within block groups increases by approximately 1 percentage point. (Recall that this magnitude is virtually identical to the one estimated for overall income variation).

Given this finding, it is perhaps not surprising that the estimated association between density and between-neighborhood inequality is extremely small. None of the three specifications produces a statistically or economically significant coefficient on the change in population density. Based on these results, there is little evidence that urban decentralization is associated with rising income differentials between neighborhoods. The negative association between density and the variance of household income observed in Table 3 seems to be driven almost entirely by the change in withinneighborhood income differences.

\section{Instrumental Variables Estimates}

One obvious criticism of this estimation is the potential endogeneity of changes in density with respect to changes in inequality. A rise in the degree of income dispersion in a metro area, for example, may induce residents to segregate further, possibly leading to greater decentralization. It is not implausible that high-income households may seek to move farther from low-income households as the gap between the two groups increases. ${ }^{12}$

I use an instrumental variables (IVs) estimation to address this matter. I consider two different sets of instruments for the change in density: (i) the lagged level of density within a metropolitan area, and (ii) lagged shares of employment in each of the nine industry shares previously considered. The rationale for each is straightforward. Initial density should capture a city's capacity for increased levels of density over time. With all else equal, initially dense cities should be less likely to see further increases in their densities because they face greater space constraints. ${ }^{13}$ Because different types of employers have different propensities to decentralize their operations (e.g., Glaeser and Kahn, 2004), initial industry shares should also predict future changes in population density. Weinberg (2004), for example, has exploited this feature of industry location patterns to instrument for job centralization in a study of spatial mismatch. Of course, because initial density or sectoral employment shares may be correlated with unobserved factors influencing subsequent changes in inequality (e.g., density or the manufacturing share in 1990 may be endogenous with respect to the change in inequality between 1990 and 2000), I use density and each industry share in 1980 to instrument for the change in density between 1990 and $2000 .^{14}$

Table 5 shows the results using all three inequality measures and all three specifications. For the sake of conciseness, I have reported only the coefficients on the change in density. The results generally are very similar to the estimates in Tables 3 and 4 . Density and inequality are negatively related, and the association operates primarily through a within-neighborhood channel rather than a between-neighborhood channel.

\footnotetext{
${ }^{12}$ Rising income differentials, for example, may generate greater differences in the demand for certain local public goods or an increasing desire to avoid "negative" neighborhood effects.

${ }^{13}$ In fact, a strong negative connection exists between the initial level of density in a metro area and the extent to which it decentralizes over the next 10 years. A simple regression of the change in density on its initial level in the data used here produces a coefficient (standard error) of $-0.04(0.004)$ with a goodness-of-fit statistic equal to 0.14 .

${ }^{14}$ As demonstrated by the results from $F$ tests of marginal significance reported in Table 5, both sets of instruments are significant predictors of the change in density between 1990 and 2000.
} 


\section{Table 5}

\section{Instrumental Variables Estimates}

\begin{tabular}{|c|c|c|c|c|c|c|}
\hline \multirow[b]{2}{*}{ Dependent variable } & \multicolumn{3}{|c|}{ IV (density) } & \multicolumn{3}{|c|}{ IV (industry shares) } \\
\hline & $I$ & II & III & $I$ & II & III \\
\hline Variance change log income distribution & $\begin{array}{c}-0.24^{*} \\
(0.06)\end{array}$ & $\begin{array}{c}-0.10^{*} \\
(0.03)\end{array}$ & $\begin{array}{c}-0.04 \\
(0.03)\end{array}$ & $\begin{array}{c}-0.07 \\
(0.05)\end{array}$ & $\begin{array}{c}-0.10^{*} \\
(0.04)\end{array}$ & $\begin{array}{c}-0.04 \\
(0.04)\end{array}$ \\
\hline Within-neighborhood inequality component & $\begin{array}{c}-0.20^{*} \\
(0.05)\end{array}$ & $\begin{array}{c}-0.11^{*} \\
(0.03)\end{array}$ & $\begin{array}{c}-0.066^{*} \\
(0.03)\end{array}$ & $\begin{array}{c}-0.07 \\
(0.05)\end{array}$ & $\begin{array}{c}-0.10^{*} \\
(0.04)\end{array}$ & $\begin{array}{c}-0.07^{*} \\
(0.04)\end{array}$ \\
\hline Between-neighborhood inequality component & $\begin{array}{c}-0.04 \\
(0.03)\end{array}$ & $\begin{array}{c}0.01 \\
(0.02)\end{array}$ & $\begin{array}{c}0.02 \\
(0.03)\end{array}$ & $\begin{array}{c}-0.003 \\
(0.04)\end{array}$ & $\begin{array}{r}0.001 \\
(0.03)\end{array}$ & $\begin{array}{c}0.03 \\
(0.03)\end{array}$ \\
\hline$F$ test & $\begin{array}{l}40.2 \\
(0)\end{array}$ & $\begin{array}{l}95.1 \\
(0)\end{array}$ & $\begin{array}{l}88.03 \\
(0)\end{array}$ & $\begin{array}{l}5.26 \\
(0)\end{array}$ & $\begin{array}{l}9.79 \\
(0)\end{array}$ & $\begin{array}{l}8.72 \\
(0)\end{array}$ \\
\hline
\end{tabular}

NOTE: Data represent 359 observations. Coefficients are for the change in log population density. Dependent variables are the changes in the variance, the within-neighborhood component, and the between-neighborhood component between 1990 and 2000 . Instruments are log density or industry employment shares in 1980. Specifications follow data reported in Tables 3 and 4 . Standard errors (reported in parentheses, except for $F$ tests) are adjusted for both heteroskedasticity and within-metro area correlation of the regression error terms. $F$ test reports results from test of the (marginal) significance of the instruments from the first-stage regression for the appropriate specification ( $p$-value under null that the IV coefficients are zero appears in parentheses). *Significant at $\geq 10$ percent.

\section{Other Measures of Between- Neighborhood Inequality}

This section expands on the analysis of between-neighborhood inequality by considering how changes in metropolitan area density influence some alternative measures of income differences across block groups. In particular, how do differences among the 90th, 50th, and 10th percentiles of the block group (average) household income distribution within each metropolitan area change as metropolitan areas decentralize? ${ }^{15}$ Although percentile differences are not typically used in studies of neighborhood income inequality, they are commonly used to quantify inequality between individuals (e.g., Juhn, Murphy, and Pierce, 1993).

Table 6 shows the results from the same three specifications considered above, each of which is estimated by OLS and IV. ${ }^{16}$ Regardless of whether the percentiles are computed in a weighted or unweighted fashion (where the weights are given by the number of households in each block group),

\footnotetext{
${ }^{15}$ On average, metropolitan areas in the sample contain 460 block groups each $($ minimum $=27$, maximum $=14,019$ ), so calculating percentiles is a reasonable exercise with these data.

${ }^{16}$ Recall that in all cases, standard errors are adjusted for heteroskedasticity and within-metro area correlation.
}

the estimated coefficients on density are quite similar. The OLS results suggest that, instead of decreases in density generating greater inequality between neighborhoods, they may generate smaller interneighborhood income differences.

This result, however, may be the product of endogeneity, whereby some aspect of rising between-neighborhood inequality may cause density to rise. For example, rising income segregation between neighborhoods may be associated with rising returns to the highly educated residents, who may desire to live in traditional city centers (e.g., Brueckner and Rosenthal, 2008). This would create an upward bias in a truly negative association between density and inequality.

I consider, therefore, the use of IVs, which produces a somewhat different set of conclusions. These suggest little association between density and the difference between the neighborhoods at the 90th and 10th percentiles of the log income distribution, which is consistent with the results examining the between-neighborhood component of total income variation documented above. When separated into 90-50 and 50-10 differentials, however, the difference between the 90th percentile and the median tends to increase significantly as 
Table 6

Alternative Measures of Between-Neighborhood Inequality

\begin{tabular}{|c|c|c|c|c|c|c|c|c|c|}
\hline \multirow[b]{2}{*}{ Dependent variable } & \multicolumn{3}{|c|}{ OLS } & \multicolumn{3}{|c|}{ IV (density) } & \multicolumn{3}{|c|}{ IV (industry shares) } \\
\hline & I & II & III & I & II & III & I & II & III \\
\hline $\begin{array}{l}\text { Unweighted } 90-10 \text { percentile } \\
\text { difference }\end{array}$ & $\begin{array}{c}0.04 \\
(0.03)\end{array}$ & $\begin{array}{c}0.07^{*} \\
(0.04)\end{array}$ & $\begin{array}{l}0.10^{*} \\
(0.04)\end{array}$ & $\begin{array}{c}-0.30^{*} \\
(0.15)\end{array}$ & $\begin{array}{c}-0.055 \\
(0.10)\end{array}$ & $\begin{array}{c}0.06 \\
(0.11)\end{array}$ & $\begin{array}{c}-0.23 \\
(0.18)\end{array}$ & $\begin{array}{l}-0.20 \\
(0.13)\end{array}$ & $\begin{array}{c}-0.07 \\
(0.13)\end{array}$ \\
\hline $\begin{array}{l}\text { Unweighted } 90-50 \text { percentile } \\
\text { difference }\end{array}$ & $\begin{array}{c}0.02 \\
(0.03)\end{array}$ & $\begin{array}{l}0.035 \\
(0.03)\end{array}$ & $\begin{array}{l}0.06^{*} \\
(0.03)\end{array}$ & $\begin{array}{c}-0.41^{*} \\
(0.10)\end{array}$ & $\begin{array}{c}-0.20^{*} \\
(0.07)\end{array}$ & $\begin{array}{c}-0.13^{*} \\
(0.07)\end{array}$ & $\begin{array}{c}-0.23^{*} \\
(0.11)\end{array}$ & $\begin{array}{r}-0.24^{*} \\
(0.08)\end{array}$ & $\begin{array}{r}-0.15^{*} \\
(0.08)\end{array}$ \\
\hline $\begin{array}{l}\text { Unweighted 50-10 percentile } \\
\text { difference }\end{array}$ & $\begin{array}{c}0.02 \\
(0.02)\end{array}$ & $\begin{array}{c}0.03 \\
(0.02)\end{array}$ & $\begin{array}{c}0.03 \\
(0.02)\end{array}$ & $\begin{array}{c}0.09 \\
(0.10)\end{array}$ & $\begin{array}{c}0.14^{*} \\
(0.07)\end{array}$ & $\begin{array}{c}0.19^{*} \\
(0.08)\end{array}$ & $\begin{array}{c}-0.01 \\
(0.11)\end{array}$ & $\begin{array}{c}0.04 \\
(0.09)\end{array}$ & $\begin{array}{c}0.07 \\
(0.10)\end{array}$ \\
\hline $\begin{array}{l}\text { Weighted } 90-10 \text { percentile } \\
\text { difference }\end{array}$ & $\begin{array}{c}0.05 \\
(0.04)\end{array}$ & $\begin{array}{l}0.067^{*} \\
(0.04)\end{array}$ & $\begin{array}{l}0.09 * \\
(0.036)\end{array}$ & $\begin{array}{c}-0.35^{*} \\
(0.13)\end{array}$ & $\begin{array}{l}-0.07 \\
(0.09)\end{array}$ & $\begin{array}{c}0.01 \\
(0.09)\end{array}$ & $\begin{array}{c}-0.08 \\
(0.17)\end{array}$ & $\begin{array}{l}-0.14 \\
(0.13)\end{array}$ & $\begin{array}{c}0.002 \\
(0.13)\end{array}$ \\
\hline $\begin{array}{l}\text { Weighted } 90-50 \text { percentile } \\
\text { difference }\end{array}$ & $\begin{array}{c}0.02 \\
(0.03)\end{array}$ & $\begin{array}{r}0.027 \\
(0.03)\end{array}$ & $\begin{array}{l}0.06^{*} \\
(0.03)\end{array}$ & $\begin{array}{c}-0.40^{*} \\
(0.10)\end{array}$ & $\begin{array}{c}-0.19^{*} \\
(0.06)\end{array}$ & $\begin{array}{c}-0.16^{*} \\
(0.07)\end{array}$ & $\begin{array}{c}-0.10 \\
(0.10)\end{array}$ & $\begin{array}{r}-0.17^{*} \\
(0.08)\end{array}$ & $\begin{array}{c}-0.09 \\
(0.08)\end{array}$ \\
\hline $\begin{array}{l}\text { Weighted 50-10 percentile } \\
\text { difference }\end{array}$ & $\begin{array}{c}0.03 \\
(0.02)\end{array}$ & $\begin{array}{c}0.04^{*} \\
(0.02)\end{array}$ & $\begin{array}{c}0.03 \\
(0.03)\end{array}$ & $\begin{array}{c}0.06 \\
(0.10)\end{array}$ & $\begin{array}{r}0.12^{*} \\
(0.06)\end{array}$ & $\begin{array}{c}0.17^{*} \\
(0.07)\end{array}$ & $\begin{array}{c}0.01 \\
(0.10)\end{array}$ & $\begin{array}{c}0.03 \\
(0.08)\end{array}$ & $\begin{array}{c}0.09 \\
(0.08)\end{array}$ \\
\hline
\end{tabular}

NOTE: Coefficients are for the change in log population density. Standard errors (reported in parentheses) are adjusted for both heteroskedasticity and within-metro area correlation of the regression error terms. Specifications follow data reported in Tables 3 and 4.

* Significant at $\geq 10$ percent.

cities decentralize. At the same time, the difference between the median and the 10th percentile appears to decrease as a metro area population spreads out. Indeed, the estimated associations between density and the 50-10 gap are significantly positive when initial density is used as an instrument for its future change. When combined, of course, these two observations are perfectly compatible with the finding that the 90-10 differential shows little association with changes in density.

This evidence suggests that, although there seems to be little association between urban decentralization and measures of the overall degree of income variation across different neighborhoods, the same is not true for all parts of the income distribution. As city populations spread out, there appears to be an increase in the average incomes of neighborhoods at the top relative to the middle. Particularly, high-income households may segregate themselves to a larger extent as populations spread out. On the other hand, the gap between the average incomes at the middle of the distribution and those at the bottom shrinks, which may reflect greater income mixing among middle- to lower-income households.
Table 7 shows a more detailed set of results describing these associations; it reports the coefficients on the change in density in regressions in which these three individual quantiles are specified as the dependent variables. The OLS results again suggest that declining density may lead to smaller income differences between block groups because the estimated associations are positive and increasing in moving from the 10th percentile to the 90th. Hence, decreases in density ought to reduce the average income at the top of the block group distribution by more than it does at either the middle or the bottom.

The OLS results may be biased, however (again, because of the likely endogeneity of changes in population density in relation to changes in inequality). IVs, therefore, may offer more reliable estimates. The IV results indicate that the 90th and 10th percentiles of the block group income distribution vary little with population density. Only two of the 24 estimates for these two quantiles differ statistically from zero. This finding is interesting because it suggests that urban decentralization is not associated with the top of the neighborhood income distribution pulling away from the rest of 


\section{Table 7}

\section{Individual Quantile Results}

\begin{tabular}{|c|c|c|c|c|c|c|c|c|c|}
\hline \multirow[b]{2}{*}{ Dependent variable } & \multicolumn{3}{|c|}{ OLS } & \multicolumn{3}{|c|}{ IV (density) } & \multicolumn{3}{|c|}{ IV (industry shares) } \\
\hline & I & II & III & I & II & III & I & II & III \\
\hline Unweighted 90th percentile & $\begin{array}{c}0.26^{*} \\
(0.03)\end{array}$ & $\begin{array}{c}0.21^{*} \\
(0.03)\end{array}$ & $\begin{array}{c}0.17^{*} \\
(0.03)\end{array}$ & $\begin{array}{c}-0.18 \\
(0.11)\end{array}$ & $\begin{array}{c}0.01 \\
(0.07)\end{array}$ & $\begin{array}{c}0.02 \\
(0.07)\end{array}$ & $\begin{array}{c}-0.08 \\
(0.11)\end{array}$ & $\begin{array}{c}-0.02 \\
(0.08)\end{array}$ & $\begin{array}{c}0.01 \\
(0.08)\end{array}$ \\
\hline Unweighted 50th percentile & $\begin{array}{c}0.24^{*} \\
(0.03)\end{array}$ & $\begin{array}{c}0.17^{*} \\
(0.02)\end{array}$ & $\begin{array}{c}0.10^{*} \\
(0.02)\end{array}$ & $\begin{array}{c}0.23^{*} \\
(0.08)\end{array}$ & $\begin{array}{c}0.21^{*} \\
(0.05)\end{array}$ & $\begin{array}{c}0.15^{*} \\
(0.05)\end{array}$ & $\begin{array}{c}0.15^{*} \\
(0.07)\end{array}$ & $\begin{array}{c}0.23^{*} \\
(0.06)\end{array}$ & $\begin{array}{c}0.16^{*} \\
(0.06)\end{array}$ \\
\hline Unweighted 10th percentile & $\begin{array}{c}0.22^{*} \\
(0.03)\end{array}$ & $\begin{array}{c}0.14^{*} \\
(0.03)\end{array}$ & $\begin{array}{c}0.07^{*} \\
(0.03)\end{array}$ & $\begin{array}{c}0.13 \\
(0.13)\end{array}$ & $\begin{array}{c}0.07 \\
(0.08)\end{array}$ & $\begin{array}{c}-0.05 \\
(0.08)\end{array}$ & $\begin{array}{c}0.16 \\
(0.12)\end{array}$ & $\begin{array}{c}0.19^{*} \\
(0.10)\end{array}$ & $\begin{array}{c}0.09 \\
(0.10)\end{array}$ \\
\hline Weighted 90th percentile & $\begin{array}{c}0.27^{*} \\
(0.04)\end{array}$ & $\begin{array}{c}0.20^{*} \\
(0.03)\end{array}$ & $\begin{array}{c}0.16^{*} \\
(0.03)\end{array}$ & $\begin{array}{c}-0.28^{*} \\
(0.12)\end{array}$ & $\begin{array}{c}-0.01 \\
(0.07)\end{array}$ & $\begin{array}{c}-0.04 \\
(0.06)\end{array}$ & $\begin{array}{c}-0.02 \\
(0.11)\end{array}$ & $\begin{array}{c}-0.02 \\
(0.08)\end{array}$ & $\begin{array}{c}-0.01 \\
(0.08)\end{array}$ \\
\hline Weighted 50th percentile & $\begin{array}{c}0.24^{*} \\
(0.03)\end{array}$ & $\begin{array}{c}0.17^{*} \\
(0.02)\end{array}$ & $\begin{array}{c}0.10^{*} \\
(0.02)\end{array}$ & $\begin{array}{c}0.13 \\
(0.08)\end{array}$ & $\begin{array}{c}0.18^{*} \\
(0.05)\end{array}$ & $\begin{array}{c}0.12^{*} \\
(0.04)\end{array}$ & $\begin{array}{c}0.08 \\
(0.07)\end{array}$ & $\begin{array}{c}0.15^{*} \\
(0.06)\end{array}$ & $\begin{array}{c}0.08 \\
(0.05)\end{array}$ \\
\hline Weighted 10th percentile & $\begin{array}{c}0.21^{*} \\
(0.04)\end{array}$ & $\begin{array}{c}0.13^{*} \\
(0.03)\end{array}$ & $\begin{array}{l}0.066^{*} \\
(0.03)\end{array}$ & $\begin{array}{c}0.07 \\
(0.11)\end{array}$ & $\begin{array}{c}0.06 \\
(0.07)\end{array}$ & $\begin{array}{c}-0.05 \\
(0.07)\end{array}$ & $\begin{array}{c}0.07 \\
(0.12)\end{array}$ & $\begin{array}{c}0.12 \\
(0.09)\end{array}$ & $\begin{array}{c}-0.01 \\
(0.09)\end{array}$ \\
\hline
\end{tabular}

NOTE: Coefficients are for the change in log population density. Standard errors (reported in parentheses) are adjusted for both heteroskedasticity and within-metro area correlation of the regression error terms. Specifications follow data reported in Tables 3 and 4.

* Significant at $\geq 10$ percent.

the distribution. It is also not associated with the bottom of the income distribution falling farther behind the remainder of the distribution. The median, however, does show significantly positive variation with density in most instances, suggesting that urban decentralization may be associated with a decline in the incomes of neighborhoods at the middle of the distribution. This result, of course, explains why the gap between the top of the income distribution rises while the gap at the bottom falls.

\section{Inequality Within and Between Tracts}

While the basic geographic unit of analysis in this paper is the block group, many existing studies of neighborhood-level economic outcomes have typically focused on Census tracts, which represent a larger geographic area. The median Census tract consists of approximately 1,649 households and covers roughly 1.3 square miles compared with 526 households and 0.33 square miles for block groups. Given the prevalence of tract-level analyses in the literature on neighborhood outcomes, this section considers whether the definition of neighborhoods as tracts, rather than block groups, alters the results in any substantive way. ${ }^{17}$
Table 8 reports the coefficients on the change in log density from every specification considered using block group-level observations. In general, the tract-level results yield very similar conclusions. The extent of income inequality observed within tracts shows a strong, negative association with population density, whereas between-tract inequality shows little correlation with density.

With regard to the percentile differences, the OLS results again suggest that, if anything, urban decentralization may be associated with smaller between-neighborhood gaps, not larger. The IV estimates are mostly insignificant, although there is some evidence that the gap between the top and middle of the neighborhood income distribution widens somewhat as population density declines. As noted previously, this finding seems to reflect a decrease in the median relative to the 90th percentile, which could be the product of greater mixing of medium- and low-income households in suburban neighborhoods.

\footnotetext{
17 On average, metropolitan areas in the sample contain 147 tracts
} each (minimum $=10$, maximum $=4,507$ ). 


\section{Table 8}

\section{Tract-Level Results}

\begin{tabular}{|c|c|c|c|c|c|c|c|c|c|}
\hline \multirow[b]{2}{*}{ Dependent variable } & \multicolumn{3}{|c|}{ OLS } & \multicolumn{3}{|c|}{ IV (density) } & \multicolumn{3}{|c|}{ IV (industry shares) } \\
\hline & $I$ & II & III & $I$ & II & III & $I$ & II & III \\
\hline Within component & $\begin{array}{c}-0.07^{*} \\
(0.009)\end{array}$ & $\begin{array}{c}-0.08^{*} \\
(0.01)\end{array}$ & $\begin{array}{c}-0.07^{*} \\
(0.01)\end{array}$ & $\begin{array}{c}-0.21^{*} \\
(0.05)\end{array}$ & $\begin{array}{c}-0.11^{*} \\
(0.03)\end{array}$ & $\begin{array}{r}-0.06^{*} \\
(0.03)\end{array}$ & $\begin{array}{c}-0.08 \\
(0.05)\end{array}$ & $\begin{array}{c}-0.10^{*} \\
(0.04)\end{array}$ & $\begin{array}{r}-0.06^{*} \\
(0.03)\end{array}$ \\
\hline Between component & $\begin{array}{l}-0.001 \\
(0.007)\end{array}$ & $\begin{array}{l}-0.005 \\
(0.008)\end{array}$ & $\begin{array}{c}-0.001 \\
(0.007)\end{array}$ & $\begin{array}{c}-0.03 \\
(0.03)\end{array}$ & $\begin{array}{c}0.009 \\
(0.02)\end{array}$ & $\begin{array}{c}0.02 \\
(0.02)\end{array}$ & $\begin{array}{l}0.005 \\
(0.04)\end{array}$ & $\begin{array}{c}0.002 \\
(0.03)\end{array}$ & $\begin{array}{c}0.02 \\
(0.03)\end{array}$ \\
\hline $\begin{array}{l}\text { Unweighted } 90-10 \text { percentile } \\
\text { difference }\end{array}$ & $\begin{array}{r}0.037 \\
(0.04)\end{array}$ & $\begin{array}{r}0.067 \\
(0.04)\end{array}$ & $\begin{array}{c}0.08^{*} \\
(0.04)\end{array}$ & $\begin{array}{c}-0.17 \\
(0.15)\end{array}$ & $\begin{array}{l}-0.0002 \\
(0.11)\end{array}$ & $\begin{array}{c}0.05 \\
(0.12)\end{array}$ & $\begin{array}{c}-0.24 \\
(0.19)\end{array}$ & $\begin{array}{c}-0.26^{*} \\
(0.15)\end{array}$ & $\begin{array}{c}-0.25 \\
(0.17)\end{array}$ \\
\hline $\begin{array}{l}\text { Unweighted 90-50 percentile } \\
\text { difference }\end{array}$ & $\begin{array}{c}0.05 \\
(0.03)\end{array}$ & $\begin{array}{c}0.05 \\
(0.03)\end{array}$ & $\begin{array}{c}0.07^{*} \\
(0.036)\end{array}$ & $\begin{array}{c}-0.26^{*} \\
(0.10)\end{array}$ & $\begin{array}{c}-0.09 \\
(0.07)\end{array}$ & $\begin{array}{l}-0.11 \\
(0.08)\end{array}$ & $\begin{array}{c}-0.17 \\
(0.12)\end{array}$ & $\begin{array}{c}-0.18^{*} \\
(0.10)\end{array}$ & $\begin{array}{c}-0.15 \\
(0.10)\end{array}$ \\
\hline $\begin{array}{l}\text { Unweighted 50-10 percentile } \\
\text { difference }\end{array}$ & $\begin{array}{c}-0.01 \\
(0.03)\end{array}$ & $\begin{array}{c}0.01 \\
(0.03)\end{array}$ & $\begin{array}{c}0.007 \\
(0.03)\end{array}$ & $\begin{array}{c}0.10 \\
(0.13)\end{array}$ & $\begin{array}{c}0.09 \\
(0.09)\end{array}$ & $\begin{array}{c}0.16 \\
(0.10)\end{array}$ & $\begin{array}{c}-0.07 \\
(0.13)\end{array}$ & $\begin{array}{c}-0.08 \\
(0.11)\end{array}$ & $\begin{array}{c}-0.10 \\
(0.13)\end{array}$ \\
\hline $\begin{array}{l}\text { Weighted } 90-10 \text { percentile } \\
\text { difference }\end{array}$ & $\begin{array}{c}0.04 \\
(0.04)\end{array}$ & $\begin{array}{c}0.056 \\
(0.04)\end{array}$ & $\begin{array}{c}0.09 * \\
(0.04)\end{array}$ & $\begin{array}{c}-0.30^{*} \\
(0.17)\end{array}$ & $\begin{array}{c}-0.09 \\
(0.12)\end{array}$ & $\begin{array}{l}-0.05 \\
(0.14)\end{array}$ & $\begin{array}{c}-0.27 \\
(0.18)\end{array}$ & $\begin{array}{c}-0.27^{*} \\
(0.15)\end{array}$ & $\begin{array}{c}-0.17 \\
(0.16)\end{array}$ \\
\hline $\begin{array}{l}\text { Weighted } 90-50 \text { percentile } \\
\text { difference }\end{array}$ & $\begin{array}{c}0.05 \\
(0.03)\end{array}$ & $\begin{array}{c}0.05 \\
(0.04)\end{array}$ & $\begin{array}{c}0.08^{*} \\
(0.04)\end{array}$ & $\begin{array}{c}-0.27^{*} \\
(0.13)\end{array}$ & $\begin{array}{c}-0.11 \\
(0.10)\end{array}$ & $\begin{array}{l}-0.08 \\
(0.11)\end{array}$ & $\begin{array}{c}-0.25^{*} \\
(0.15)\end{array}$ & $\begin{array}{c}-0.25^{*} \\
(0.12)\end{array}$ & $\begin{array}{r}-0.21^{*} \\
(0.13)\end{array}$ \\
\hline $\begin{array}{l}\text { Weighted 50-10 percentile } \\
\text { difference }\end{array}$ & $\begin{array}{c}-0.01 \\
(0.02)\end{array}$ & $\begin{array}{c}0.005 \\
(0.03)\end{array}$ & $\begin{array}{c}0.01 \\
(0.03)\end{array}$ & $\begin{array}{c}-0.03 \\
(0.12)\end{array}$ & $\begin{array}{c}0.02 \\
(0.08)\end{array}$ & $\begin{array}{c}0.03 \\
(0.10)\end{array}$ & $\begin{array}{c}-0.01 \\
(0.12)\end{array}$ & $\begin{array}{c}-0.02 \\
(0.10)\end{array}$ & $\begin{array}{c}0.04 \\
(0.11)\end{array}$ \\
\hline Unweighted 90th percentile & $\begin{array}{c}0.30^{*} \\
(0.04)\end{array}$ & $\begin{array}{c}0.24^{*} \\
(0.04)\end{array}$ & $\begin{array}{c}0.19 * \\
(0.04)\end{array}$ & $\begin{array}{c}-0.05 \\
(0.11)\end{array}$ & $\begin{array}{c}0.10 \\
(0.07)\end{array}$ & $\begin{array}{c}0.01 \\
(0.08)\end{array}$ & $\begin{array}{c}-0.05 \\
(0.13)\end{array}$ & $\begin{array}{c}0.02 \\
(0.10)\end{array}$ & $\begin{array}{c}-0.04 \\
(0.10)\end{array}$ \\
\hline Unweighted 50th percentile & $\begin{array}{r}0.25^{*} \\
(0.03)\end{array}$ & $\begin{array}{c}0.18^{*} \\
(0.02)\end{array}$ & $\begin{array}{c}0.11^{*} \\
(0.02)\end{array}$ & $\begin{array}{c}0.21^{*} \\
(0.08)\end{array}$ & $\begin{array}{c}0.19^{*} \\
(0.05)\end{array}$ & $\begin{array}{c}0.12^{*} \\
(0.06)\end{array}$ & $\begin{array}{c}0.12 \\
(0.08)\end{array}$ & $\begin{array}{c}0.20^{*} \\
(0.07)\end{array}$ & $\begin{array}{r}0.10^{*} \\
(0.06)\end{array}$ \\
\hline Unweighted 10th percentile & $\begin{array}{c}0.26^{*} \\
(0.04)\end{array}$ & $\begin{array}{c}0.17^{*} \\
(0.03)\end{array}$ & $\begin{array}{c}0.11^{*} \\
(0.03)\end{array}$ & $\begin{array}{c}0.12 \\
(0.13)\end{array}$ & $\begin{array}{c}0.10 \\
(0.09)\end{array}$ & $\begin{array}{c}-0.04 \\
(0.09)\end{array}$ & $\begin{array}{c}0.19 \\
(0.14)\end{array}$ & $\begin{array}{c}0.28^{*} \\
(0.12)\end{array}$ & $\begin{array}{c}0.21^{*} \\
(0.12)\end{array}$ \\
\hline Weighted 90th percentile & $\begin{array}{c}0.27^{*} \\
(0.04)\end{array}$ & $\begin{array}{c}0.20^{*} \\
(0.03)\end{array}$ & $\begin{array}{c}0.17^{*} \\
(0.04)\end{array}$ & $\begin{array}{c}-0.15 \\
(0.13)\end{array}$ & $\begin{array}{c}0.03 \\
(0.09)\end{array}$ & $\begin{array}{c}-0.01 \\
(0.10)\end{array}$ & $\begin{array}{c}-0.14 \\
(0.14)\end{array}$ & $\begin{array}{c}-0.09 \\
(0.11)\end{array}$ & $\begin{array}{c}-0.11 \\
(0.12)\end{array}$ \\
\hline Weighted 50th percentile & $\begin{array}{c}0.23^{*} \\
(0.03)\end{array}$ & $\begin{array}{c}0.15^{*} \\
(0.02)\end{array}$ & $\begin{array}{c}0.08^{*} \\
(0.02)\end{array}$ & $\begin{array}{c}0.12 \\
(0.08)\end{array}$ & $\begin{array}{c}0.14^{*} \\
(0.06)\end{array}$ & $\begin{array}{c}0.07 \\
(0.06)\end{array}$ & $\begin{array}{c}0.11 \\
(0.08)\end{array}$ & $\begin{array}{c}0.16^{*} \\
(0.06)\end{array}$ & $\begin{array}{c}0.10^{*} \\
(0.06)\end{array}$ \\
\hline Weighted 10th percentile & $\begin{array}{c}0.23^{*} \\
(0.04)\end{array}$ & $\begin{array}{c}0.15^{*} \\
(0.03)\end{array}$ & $\begin{array}{c}0.07^{*} \\
(0.03)\end{array}$ & $\begin{array}{c}0.15 \\
(0.13)\end{array}$ & $\begin{array}{c}0.12 \\
(0.08)\end{array}$ & $\begin{array}{c}0.05 \\
(0.10)\end{array}$ & $\begin{array}{l}0.13 \\
(0.11)\end{array}$ & $\begin{array}{c}0.17^{*} \\
(0.10)\end{array}$ & $\begin{array}{c}0.07 \\
(0.11)\end{array}$ \\
\hline
\end{tabular}

NOTE: Coefficients are for the change in log population density. Standard errors (reported in parentheses) are adjusted for both heteroskedasticity and within-metro area correlation of the regression error terms. Specifications follow data reported in Tables 3 and 4.

*Significant at $\geq 10$ percent. 
Thus, just as with block groups, urban decentralization tends to be accompanied by widening income gaps within Census tracts. There is little evidence that between-neighborhood income gaps rise in sprawling cities.

\section{CONCLUSION}

City populations in the United States have decentralized for more than a century. Although the process was driven largely by the decisions of individuals to live farther from historical city centers, it has generated numerous concerns about segregation of households by income. Given the evidence documented in previous work and herein that urban decentralization tends to be accompanied by significant increases in income inequality, these concerns certainly seem warranted.

This paper has examined this issue further by exploring the extent to which the increased income inequality with decreasing density emanates from a rise in the degree of income variation exhibited across different neighborhoods. In general, the findings suggest that between-neighborhood income gaps do not rise significantly as central cities spread out. Neither the difference between the 90th and 10th percentiles of the block group-level income distribution nor the degree of variation associated with between-block group income differentials rises (or falls) significantly as a metropolitan area's population spreads out. This result should not be interpreted as suggesting that all betweenneighborhood income differentials are completely invariant to the outward movement of people in a city. A rising gap between the absolute poorest neighborhoods and the remainder of the metropolitan area may still exist. However, the extent to which this potential gap contributes to overall income inequality within a local market appears decidedly small.

Instead, the rise of income dispersion as cities decentralize is largely associated with an increase in the degree of income heterogeneity within neighborhoods. One straightforward interpretation of this result is that urban decentralization is associated with greater income mixing within neighborhoods, regardless of whether they are defined by block groups or tracts. Because they are less densely populated, for instance, suburban neighborhoods may more readily accommodate households with widely varying income levels than central cities, where individuals reside in closer proximity. This may be similar to the finding reported by Glaeser and Kahn (2004) that suburbs are more racially integrated than central cities.

Unfortunately, why overall income inequality increases with urban decentralization remains unresolved. If sprawling cities were simply reorganizing their populations from dense, segregated collections of neighborhoods into less-dense, heterogeneous sets of neighborhoods, the rise in withinneighborhood inequality should be offset by a drop in between-neighborhood inequality. The data show little evidence of any such drop.

One possible explanation is that urban decentralization may be associated with greater industrial heterogeneity (beyond what this analysis controls for), at least in the sense that suburban areas might have large numbers of particularly low-wage jobs, high-wage jobs, or both. A large presence of jobs in typically low-wage sectors, such as food services and accommodation or retail trade, for example, may contribute to higher inequality within neighborhoods. On a more speculative level, less-dense suburban areas might be characterized by fewer social interactions among individuals of different groups, as defined by income or education. That is, although suburban neighborhoods may have a more heterogeneous mix of residents, the extent of productive interaction among them may be relatively low. Following Glaeser (1999), this may lead to greater income inequality as "less-skilled" workers have fewer opportunities to learn from their "more-skilled" counterparts.

At this point, both explanations are purely hypothetical and, therefore, require greater research. Given the relative dearth of studies of the inequalityurban decentralization issue, such research certainly seems worthwhile.

\section{REFERENCES}

Abramson, Alan J.; Tobin, Mitchell S. and VanderGoot, Matthew R. "The Changing Geography of Metropolitan Opportunity: The Segregation of the Poor in Metropolitan Areas, 1970 to 1990." Housing 


\section{Wheeler}

Policy Debate, 1995, 6(1), pp. 45-72; www.fanniemaefoundation.org/programs/hpd/pdf/ hpd_0601_abramson.pdf.

Benabou, Roland. "Heterogeneity, Stratification, and Growth: Macroeconomic Implications of Community Structure and School Finance." American Economic Review, 1996, 86, pp. 584-609.

Brueckner, Jan K. and Rosenthal, Stuart S. "Gentrification and Neighborhood Housing Cycles: Will America's Future Downtowns Be Rich?" CESifo Working paper series No. 1579, University of California-Irvine, April 2, 2008; www.socsci.uci.edu/ jkbrueck/gentrification.pdf.

Epple, Dennis and Sieg, Holger. "Estimating Equilibrium Models of Local Jurisdictions." Journal of Political Economy, August 1999, 107(4), pp. 645-81.

Fortin, Nicole M. and Lemieux, Thomas. "Institutional Changes and Rising Wage Inequality: Is There a Linkage?" Journal of Economic Perspectives, Spring 1997, 11(2), pp. 75-96.

Glaeser, Edward L. "Learning in Cities.” Journal of Urban Economics, September 1999, 46(2), pp. 254-77.

Glaeser, Edward L. and Kahn, Matthew E. "Sprawl and Urban Growth," in J. Vernon Henderson and Jacques-François Thiesse, eds., Handbook of Regional and Urban Economics, volume 4: Cities and Geography (Handbooks in Economics), chapter 56. New York: Elsevier, 2004, pp. 2481-528.

Hardman, Anna and Ioannides, Yannis. "Neighbors' Income Distribution: Economic Segregation and Mixing in US Urban Neighborhoods." Journal of Housing Economics, December 2004, 13(4), pp. 368-82.

Hirsch, Barry T.; Macpherson, David A. and Vroman, Wayne G. "Estimates of Union Density by State." Monthly Labor Review, July 2001, 124(7), pp. 51-55; http://www.bls.gov/opub/mlr/2001/07/ressum2.htm.

Hobbs, Frank and Stoops, Nicole. "Demographic Trends in the 20th Century." US Census Bureau, Census 2000 Special Reports, Series CENSR-4 (November 2002). Washington, DC: US Government Printing Office; www.census.gov/prod/2002pubs/censr-4.pdf.
Holzer, Harry J. "The Spatial Mismatch Hypothesis: What Has the Evidence Shown?" Urban Studies, February 1991, 28(1), pp. 105-22.

Ihlanfeldt, Keith R. and Sjoquist, David L. "The Impact of Job Decentralization on the Economic Welfare of Central City Blacks.” Journal of Urban Economics, July 1989, 26(1), pp. 110-30.

Ioannides, Yannis M. "Neighborhood Income Distributions." Journal of Urban Economics, November 2004, 56(3), pp. 435-57.

Johnson, Norman L. and Kotz, Samuel. Continuous Univariate Distributions. Boston: Houghton Mifflin, 1970.

Juhn, Chinhui; Murphy, Kevin M. and Pierce, Brooks. "Wage Inequality and the Rise in Returns to Skill." Journal of Political Economy, 1993, 101(3), 410-42.

Kain, John F. "Housing Segregation, Negro Employment, and Metropolitan Decentralization." Quarterly Journal of Economics, May 1968, 82(2), pp. 175-97.

Kasarda, John D. "Inner-City Concentrated Poverty and Neighborhood Distress: 1970-1990.” Housing Policy Debate, 1993, 4(3), pp. 253-302.

Katz, Lawrence K. and Murphy, Kevin M. "Changes in Relative Wages, 1963-1987: Supply and Demand Factors." Quarterly Journal of Economics, February 1992, 107, 35-78.

Margo, Robert A. "Explaining the Postwar Suburbanization of the Population of the United States: The Role of Income." Journal of Urban Economics, May 1992, 31(3), pp. 301-10.

Mayer, Christopher J. "Does Location Matter?” New England Economic Review, May/June 1996, pp. 26-40.

Weinberg, Bruce A. "Black Residential Centralization and the Spatial Mismatch Hypothesis." Journal of Urban Economics, July 2000, 48(1), pp. 110-34.

Weinberg, Bruce A. “Testing the Spatial Mismatch Hypothesis Using Inter-City Variations in Industrial Composition." Regional Science and Urban Economics, September 2004, 34(5), pp. 505-32. 
Wheeler, Christopher H. "Wage Inequality and Urban Density." Journal of Economic Geography, 2004, 4(4), pp. 421-37.

Wilson, William J. The Truly Disadvantaged: The Inner City, the Underclass, and Public Policy. Chicago: University of Chicago Press, 1987.
Yang, Rebecca and Jargowsky, Paula. "Suburban Development and Economic Segregation in the 1990s." Journal of Urban Affairs, June 2006, 28(3), pp. 253-73.

\section{APPENDIX}

\section{Income Categories Used in Analysis*}

1980 Income Categories (\$)

$\begin{array}{cc}0-4,999 & 0-4,999 \\ 5,000-7,499 & 5,000-9,999 \\ 7,500-9,999 & 10,000-12,499 \\ 10,000-12,499 & 12,500-14,999 \\ 12,500-14,999 & 15,000-17,499 \\ 15,000-17,499 & 17,500-19,999 \\ 17,500-19,999 & 20,000-22,499 \\ 20,000-22,499 & 22,500-24,999 \\ 22,500-24,999 & 25,000-27,499 \\ 25,000-27,499 & 27,500-29,999 \\ 27,500-29,999 & 30,000-32,499 \\ 30,000-34,999 & 32,500-34,999 \\ 35,000-39,999 & 35,000-37,799 \\ 40,000-49,999 & 37,500-39,999 \\ 50,000-74,999 & 40,000-42,499 \\ - & 42,500-44,999 \\ - & 45,000-47,499 \\ - & 47,500-49,999 \\ - & 50,000-54,999 \\ - & 55,000-59,999 \\ - & 60,000-74,999 \\ - & 75,000-99,999 \\ - & 100,000-124,499 \\ - & 125,000-149,999\end{array}$

2000 Income Categories (\$)

$0-9,999$

10,000-14,999

15,000-19,999

20,000-24,999

25,000-29,999

$30,000-34,999$

$35,000-39,999$

40,000-44,999

$45,000-49,999$

$50,000-59,999$

$60,000-74,999$

$75,000-99,999$

100,000-124,999

125,000-149,999

150,000-199,999

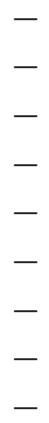

NOTE: * See footnote 6 . 